\title{
Prediction of changes in the state of the geological environment in the mining region
}

\author{
Olena Bubnova ${ }^{1, *}$ \\ ${ }^{1}$ Institute of Geotechnical Mechanics named by N. Poljakov of National Academy of Sciences of \\ Ukraine, 49005, Dnipro, Simferopolska Str., 2a, Ukraine
}

\begin{abstract}
The mining industry is fundamental in the violation of the natural environment and the creation of technogenic. Due to the fact that the natural, disturbed and technogenic environments are in direct contact with each other, there are a number of interrelations between them that affect the general state of the environment. It is shown that the interaction of disturbed and technogenic arrays with the natural geological environment leads to the development of negative processes in the form of landslides, flooding and drainage of territories. In turn, these negative processes lead to the formation of secondary disturbances in the natural environment and directly in disturbed and technogenic arrays - additional sedimentation and deformation of rocks, the formation of dips. The main reason for the development of such hazardous processes is the violation of the hydrogeological regime in the vast territories adjacent to the mine workings. Studies of the hydrogeological and hydrological regimes in disturbed and technogenic arrays are given. The processes of landslide formation and their causes in quarries and in dumps of enterprises mining various types of minerals are considered.
\end{abstract}

\section{Introduction}

About 700 enterprises in Ukraine produce mining of ores, coal, non-metallic materials and building materials by open and underground methods. On average, about 1.2-1.4 billion $\mathrm{m}^{3}$ of rock mass is extracted annually from the subsoil and, accordingly, the same volume of voids is formed, which are filled with overlying rocks (when the rocks mass subsidences), water and gas, or remain free for a long time. Extracted at the same time as mineral resources, overburden rocks and enrichment waste are stored on the earth's surface, occupying areas exceeding disturbed massifs. In each of the massifs created as a result of mining, a number of natural and technogenic processes occur, the natural geological environment undergoes significant changes with the loss of natural properties, which not only adversely affects the state of the environment, but also leads to the development of dangerous secondary disturbances.

Due to the fact that the natural environment and disturbed / technogenic massifs are in direct contact with each other (as in plan well as in depth), there are a number of

\footnotetext{
Corresponding author: bubnova@nas.gov.ua
} 
interrelations between them that affect the general state of the environment.

The relationship of technogenic and disturbed arrays with the natural geological environment is manifested in:

1) the process of formation of the disturbed / technogenic massif;

2) location in relation to each other: direct adjacent in horizontal or vertical planes;

3) mutual influence in the process of functioning: change in properties, development of deformation and natural and technogenic processes.

Contacting natural and disturbed / technogenic geological environments leads to the violation of a number of properties and processes in the natural environment. Moreover, for the theoretical determination of changes in the parameters of the natural environment, it is necessary to take into account the location of the man-made environment in the natural environment, since the forms and intensity of the manifestation of their deformation interactions depend on the geological and hydrogeological structure of the massif.

The location of the technogenic geological environment in relation to the natural (natural) is important: the junction in the horizontal or vertical plane (above or below the natural), because as a result of the impact of exogenous processes, the natural and technogenic geological environment acquire new properties, especially in relation to the water exchange system.

In the process of interaction of disturbed and technogenic arrays with the natural geological environment, there is a disturbance of the equilibrium state of the natural environment, which is manifested in subsidence, the formation of landslides, failures, flooding of territories, decrease in soil fertility.

\section{The overview of research}

The issues of the earth surface subsidence are well studied through proper empirical models by statistical analysis of both fuzzy methods and artificial neural network [1].

The problems of landslides formation are not less well studied. At the same time, the scientists take into account the conditions for the natural and artificial rocky slopes formation, the presence of geological disturbances, the height of the seams (layers), the angles of slopes and other conditions that causes the sliding of the rock [2]. In addition, there are scientific works that consider the formation of landslides as a result of subsidence of rocks under dumps with account of the amount of precipitation [3].

The geomechanical problems of inside dumps stability are studied in the work [4], and the criteria for landslides formation in the dumps are studied in the work [5]. The authors propose to consider a number of factors of natural, technogenic and technological nature in assessing the dumps stability with account of changes in the geomechanical properties of their bases.

In a number of scientific publications it is noted the need to take into account the wetting of soils when determining their subsidence under loading [6], as well as the amount of water content in determining the deformation behaviour of soils [7].

Also in the work [8], it is pointed out the importance of taking into account of changes in the hydrogeologic regime when predicting the development of landslide formation.

The authors of the work [9] propose to perform the modelling of hydrogeologic regime change with the use of the Monte Carlo method, which shows the best results in integrated modelling of such processes.

At the same time, at present in the world practice, it is not taken into account the change in the hydrogeological, hydrologic regimes associated with the accumulation of dumps and slurry storages, as well as the surface subsidence under such technogenic objects, which is connected with such a change.

The properties of technogenic rocks, features of the joint functioning of man-made, 
disturbed and natural geological environments have also been insufficiently studied.

\section{Results and discussion}

\subsection{Land area subsidence in the mining region}

Known is the fact of subsidence of the earth's surface during underground mining of minerals. This question has been rather well studied and described by analytical and empirical dependencies containing the thickness of the reservoir being extracted.

At the same time, with the underground mining method, subsidence of the earth's surface is observed, exceeding the thickness of the extracted layer. Subsidence is also observed in the territory adjacent to the quarries, which necessitates studying this process from the point of view of the influence of drainage works on it, which lead to the compaction of water-containing rocks, but are not taken into account by regulatory acts.

Under the action of a continuous load extending over considerable distances, and with a decrease in pore pressure, a structural change in the rocks of the aquifers occurs; decreases their porosity and porosity coefficient. This leads to the subsidence of the earth's surface over a large area.

For rocks of a natural undisturbed structure, the curve of variation of the porosity coefficient from a load of [10] has two sections (Fig. 1): the first $a b$ is up to pressures $P_{0}$ that do not exceed the structural strength of rocks with very small changes in the porosity ratio, and the second is curvilinear, with significant changes the porosity factor, which indicates the compaction of rocks under load, exceeding the structural strength of rocks. At lower loads, compaction of rocks does not occur.

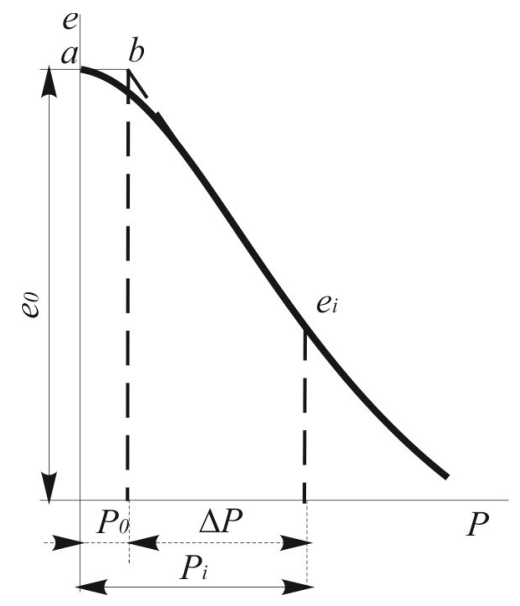

Fig. 1. The change in the porosity factor of the load [10].

For pressures that are greater than the structural strength of rocks, the porosity factor depends on the logarithm of changes in external pressure. For a large pressure range, it is determined by the expression [10]

$$
e_{i}=e_{0}-C_{c} \ln \left(\frac{P_{i}}{P_{0}}\right)
$$

where $e_{0}$ and $P_{0}$ are the initial porosity factor and pressure close to the value of structural strength; $e_{i}$ and $P_{i}$ porosity factor and pressure, corresponding to the $i$-th step of 
the load; $C_{c}$ - the compression factor (the slope ratio of semilogarithmic curve to the pressures axis).

One can judge about a change in the porosity factor of aquifers from a decrease in the water level in observation boreholes or from subsidence of the earth surface. With a decrease in the water level in the boreholes in the process of drawdown, the ratio of increased pressure on water-bearing rocks to the original pressure is the same as the ratio of water levels: of the sum of initial level and the value of decrease in the level to the initial one. Then the dependence of the porosity factor on change in the water level in the boreholes can be represented as follows

$$
e_{i}=e_{0}-C_{c} \ln \left(\frac{H_{0}+\Delta H}{H_{0}}\right),
$$

where $H_{0}$ - the height of the water column in the borehole at the beginning of observations from the water table to the aquifer, which is dewatered, $\mathrm{m} ; \Delta H-$ a change in water level in the borehole relative to the original one, $\mathrm{m}$.

Under the influence of a constant load that extends over considerable distances, the amount of following during compaction of rocks is determined by the expression [10] by

$$
\eta^{\prime}=m_{v} \frac{e_{0}-e_{1}}{1+e_{0}}
$$

where $m_{v}-$ the thickness of aquifer, $\mathrm{m}$.

When compacting the rocks of the aquifer, the value of subsidence is determined by the following author's formula [11]

$$
\eta=q_{0} m_{v}\left(\sqrt[3]{\frac{e_{0}}{1+e_{0}}}-\sqrt[3]{\frac{e_{i}}{1+e_{i}}}\right), \mathrm{m}
$$

where $q_{0}$ - the settlement factor, taking into account the dewatering and degassing of rocks.

Thus, knowing the value of drawdown in the boreholes, and the aquifer, due to which it happens, a change in the porosity factor can be determined by expression (2), and the value of the earth surface subsidence can be determined with the use of expression (4).

To calculate the area of the geomechanical processes development, which are caused by drawdown, it is proposed to determine the radius of the depression by the author's formula

$$
R=r \cdot e^{\frac{\pi \cdot K_{f}\left(H_{0}-H_{c} \pm 0.5 A\right)}{Q}}
$$

where $r$ - the radius of lands disturbed by mining operations, $\mathrm{m} ; Q$ - the daily mine drainage / open-pit mine drainage, $\mathrm{m}^{3} /$ day; $K_{f}$ - the average coefficient of permeability in rocks of quaternary deposits and carbon, cub. m/day; $H_{C}, H_{0}$ - the height of the water level at the beginning and at the end of the depression pit, respectively; $A$ - the amplitude of seasonal variation in underground water level (with the "+" sign during the spring and autumn increase, with the "-" sign - in the summerwinter decrease).

The proposed mathematical apparatus has been tested at actual data based on field regime observations for the Nikopol - Marhanets and Kryvyi Rih basins with a good convergence of the results. 


\subsection{Flooding of mining regions}

One of the problematic issues is the flooding of the territories, especially where mining enterprises operate.

Hydrogeological services establish the magnitude of the rise of groundwater and their stabilization. Developed various measures to reduce the level of groundwater. However, no tangible results.

It is considered that the main objects that lead to flooding of the adjacent territories are tailing dumps, and the main reason is water leakage from these hydraulic structures. But along with this there is another one, caused by the creation of a technogenic geological environment in the form of a specially laid sandy-silt-clay mixture (the content of dusty particles is over $60 \%$, clayey is 0.4 , the rest is sands). Dust and clay particles are concentrated in the center of the tailings and covered with water (to avoid dusting). The creation of tailings has violated the natural regime of surface and groundwater. A common characteristic feature of all tailing ponds is that they are located in the upper reaches of the ravines or ravines of the river valleys, which with their mouths extend to the rivers. Beams, ravines are composed of loess and loess-like rocks, which are used for feeding and unloading groundwater. The high vertical porosity of the loesslike rocks contributes to the infiltration of precipitation, the feeding of groundwater. Groundwater is discharged into beams, river valleys, ravines. When creating in the upper gutters of the technogenic geological environment, the possibility of groundwater discharge and the corresponding river feeding are excluded. This leads, on the one hand, to practically the liquidation of the rivers, and on the other, to the flooding of the area around the tailings.

Thus, the elimination of places of natural discharge of groundwater is one of the causes of rising groundwater levels.

In addition, in our opinion, raising the level of groundwater and, as a result, the flooding of human settlements is due to the obstruction of the natural movement of water by areas disturbed by mining. The volume of water remains the same, but the area of its distribution decreases; the direction of movement of groundwater changes - they flow around the obstacle.

On this basis, the magnitude of the increase in groundwater level at a certain point in time will be equal to [12]

$$
h=\frac{S_{d} \cdot m_{0}}{S_{0}-S_{d}},
$$

where $S_{0}$ - the area of undisturbed land at the moment of time taken as a point of reference (the initial area of land in which the state of the aquatic environment is not disturbed by mining); $m_{0}$ - initial thickness of layer water-bearing rocks; $S_{d}$ - area disturbed by mining.

The quantity increase the groundwater level, determined by expression (6) is not constant. It changes in time, that is, it has a certain rate of change. Assume that the rate of disturbance of the geological environment is equal to $v_{n}$ per unit of time, for example, a year, is constant and peculiar only to this field. Then the rate of rise of the groundwater level $v_{a v}$ for the period of operation of the field $T$ will be

$$
v_{a v}=\frac{v_{n} \cdot m_{0}}{S_{0}-v_{n} T}
$$

Violation of the natural geological environment adjacent to the disturbed during mining is determined for each mining region separately, depending on the method and technology of mining. 
The size of the disturbed geological environment by area for the planned period can be determined as follows

$$
S_{d}=S_{d p 1}+S_{d p 2}
$$

where $S_{d p 1}$ - total area of disturbed geological environment prior to the execution of works for the planned period, $\mathrm{m}^{2} ; S_{d p 2}$ - area of disturbed geological environment for the planned period, $\mathrm{m}^{2}$.

The area of disturbed geological environment for the planned period can be determined as follows

$$
S_{d p 2}=l_{p} \cdot L_{f}+\frac{V_{v}}{h_{0}}, \mathrm{~m}^{2}
$$

where $l_{p}$ - annual exploitation of mining operations, $\mathrm{m} ; L_{f}-$ the length of the work front, $\mathrm{m} ; V_{v}$ - annual volume of overburden works stored in the external dump, $\mathrm{m}^{3} ; h_{0}$-height of the dump, $m$.

When forecasting changes in the state of the geological environment in the development of mineral deposits, the height $h_{p}$, the magnitude of which will increase the level of groundwater can be determined

$$
h_{p}=\frac{\left(h_{O C}-h_{i}\right) S_{d} K_{s t} K_{s t}^{\prime}}{S-S_{d}}, \mathrm{~m},
$$

where $h_{O C}$ - precipitation, $\mathrm{m} ; h_{i}$ - evaporation, m; we accept the same in natural and man-made geological environments (although this is not the case, and requires research in specific conditions); $K_{s t}, K_{s t}^{\prime}$ - runoff coefficients in natural and technogenic geological environments, respectively; $S, S_{d}$ - respectively, the entire area under consideration and disturbed, $\mathrm{m}^{2}$.

As follows from expression (10), the rise of the level of groundwater increases hyperbolically depending on the area of the technogenic geological environment.

\subsection{Landslide processes}

One of the manifestations of the interaction of technogenic and natural geological environment are landslides. The problem of studying landslide-prone sites in Ukraine every year is becoming increasingly important.

Landslides are the most dangerous exogenous geological processes that can lead to catastrophic consequences. More than 20 thousand landslides were recorded on the territory of Ukraine and their number is constantly increasing. The official statistics on landslide processes relate only to the territories of settlements, but do not take into account their presence on technogenic objects, such as dumps of mine and quarry rocks, pit walls, bulk dams, etc.

At the listed facilities of the mining and processing industries, the boundary between the technogenic and natural environment is pronounced. Therefore, it is by their example that we consider the relationship between technogenic and natural geological environments.

Contacting natural and technogenic geological environments leads to the violation of a number of properties and processes in the natural environment. Moreover, for the theoretical determination of changes in the parameters of the natural environment, it is necessary to take into account the location of the technogenic environment in the natural environment, since the forms and intensity of the manifestation of their deformation interactions depend on the geological and hydrogeological structure of the massif. 
The reason for the development of landslide processes is the contacting of different types of media with each other and the influence of groundwater and surface water, the movement of which as a result of dumping and the formation of sludge collectors was blocked, and not the technology of laying rocks, as is commonly believed.

It is known from mechanics that when different bodies touch, friction forces arise that prevent them from moving. According to Coulon's law, the friction force is

$$
F_{t r}=\mu \cdot N,
$$

where $\mu$-coefficient of friction, depending on the nature and properties of the rubbing surfaces; $N$ - force of normal pressure.

For the conditions of ensuring the stability of the system, the angle of external friction of the destroyed rocks is important. In [14], the authors proposed an analytical dependence for determining the angle of external friction of rocks depending on their size

$$
\varphi^{\prime}=67.7 \cdot d^{-0.145}, \mathrm{deg}
$$

where $d$ - size of broken rock pieces, mm.

Figure 2 shows a graph constructed from (12), taking into account the composition of the exploded mass of Krivbas quarries. From the above it is obvious that the friction is greater, the smaller the piece of destroyed rock. Thus, during the formation of internal dumps with ensuring their stability, it is necessary to substantiate the size of the lumps stored in the dumps.

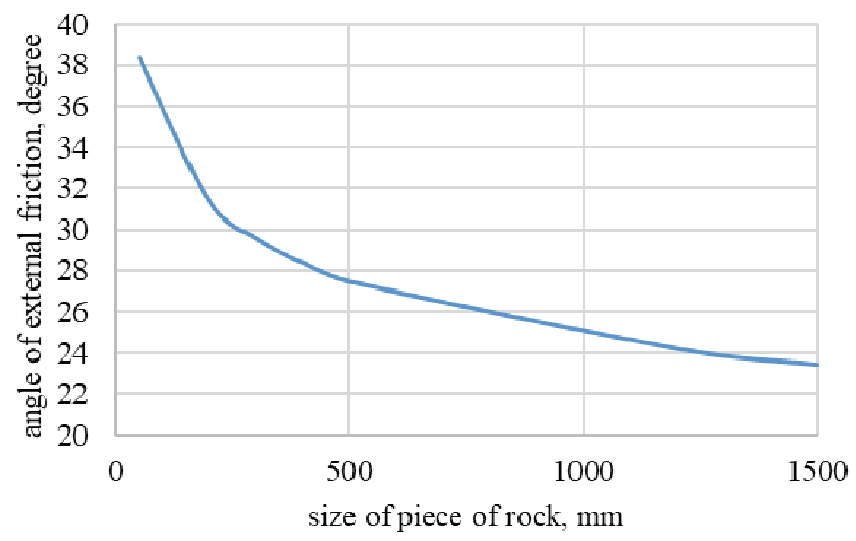

Fig. 2. Dependence of the angle of external friction of the destroyed rock from the size of its piece.

In addition to the risk of a deposit on the contact of the quarry-internal dump, the slope of the internal or external dump itself is a landslide. In [15], the authors proved that the accelerated development of landslides in the dumps is characteristic of the conditions for the storage of rocks of low strength or uniform grainstack. In analytical studies of the parameters of an elastoplastic state, the most commonly used is the Mohr strength criterion with the rectilinear envelope of limit circles of principal stresses.

The criterion assumes that the collapse occurs along the plane without any expansion. The Coulon-Mohr criterion can be expressed in fundamental stresses as

$$
\frac{\sigma_{1}}{\sigma_{3}}=\frac{2 C \cos \varphi}{\sigma_{3}(1-\sin \varphi)}+\frac{1+\sin \varphi}{1-\sin \varphi}
$$

where $\sigma_{1}$ and $\sigma_{3}$ - the greatest and least voltage; $C$ - clutch; $\varphi$ - the angle of internal friction. 
The adhesion of the destroyed rocks depends on the granulometric composition and the shape of the pieces of the rock. Thus, both the slipping and the collapse of the slopes of the dumps are due to the grains of the accumulated mountain mass.

Thus, the more durable and heterogeneous the granosous rock forms in the blade, the greater the stability of the blade.

In addition to the interaction of different types of rocks, the development of landslide processes leads to the influence of underground and surface waters.

One example of the interaction of the technogenic and natural environment, which led to dangerous deformation processes, is the creation of an internal deflection in Chkalov's Quarry \# 1 of Pokrovskyi GZK.

In the process of changing the direction of the development of mining operations from the north to the east (in connection with the development of reserves in the north), the movement of groundwater was blocked, which led to the displacement of previously deposited and reclaimed rocks.

The formation of a landslide occurred as a result of overlapping of the movement of groundwater and raising their level in the zone of unfinished rocks of the dump, i.e. disturbances of the interconnection of the water system in natural and technogenic geological environments: this subsequently led to a decrease in the strength of clayey rocks as a result of their humidification, hydrostatic pressure, exposure to the dump on the eastern side when forming a new cut trench. The development of the landslide was affected by the loading of the reclaimed part of the dump through the open rocks.

Creation of a decomposition of open-pit rock Annovskyi Quarry of SevGZK (technogenic medium), the sole of which is located on three girders (natural environment), led to the manifestation of landslide processes on the northwest shovel and eastern side of the Annovskyi Quarry [16].

The formation of a landslide occurred as a result of overlapping of the movement of groundwater and raising their level in the zone of unfinished rocks of the dump, i.e. disturbances of the interconnection of the water system in natural and technogenic geological environments: this subsequently led to a decrease in the strength of clayey rocks as a result of their humidification, hydrostatic pressure, exposure to the dump on the eastern side when forming a new cut trench. The development of the landslide was affected by the loading of the reclaimed part of the dump through the open rocks.

Creation of a decomposition of open-pit rock Annovskyi Quarry of SevGZK (technogenic medium), the sole of which is located on three girders (natural environment), led to the manifestation of landslide processes on the northwest shovel and eastern side of the Annovskyi Quarry [16].

The reason for the development of landslide processes is the influence of underground and surface waters, the movement of which as a result of dredging was covered, and not the technology of laying the rocks, as is commonly believed.

Surface waters accumulate under the surface of the dump and find an exit in the form of fountain sources on the upper tiers, and from under the soles of the dump, forming swamps. The slope of the upper deck surface is directed from the south to the north, which provides the drainage of surface waters to the north to the section between the dump and the quarry.

The movement of water in the area of the section separating the dump from the quarry is directed from the north to the south by two streams (in accordance with the general slope of the surface). They accumulate in the south near the eastern non-working side of the dump in the tales of beams. Such a movement of groundwater leads to the development of landslides.

The same situation developed at the Zavvaliev combine. The conducted analysis of geological and hydrogeological conditions, hydrology and terrain in the region of the Southeast Quarry of the Zavvaliev graphite deposit indicates that the main cause of the 
landslide processes of the northern and northwestern sides of the quarry is the influence of the technogenic object (quarry) on the natural environment (natural environment).

The northern side of the quarry crosses three large beams with a large hydraulic slope, eastward, central and western, along its stretch. These beams earlier (before the creation of a career) fed the river South Buh and clustered south of the existing career. The food came from surface waters flowing through the talismans of beams, and underground, which followed from the Baltic sands from north to south and from northeast to southwest.

The slippery landslide processes that occurred along the northern and northeastern sides of the quarry in sedimentary deposits are the result of the intersection of the working front of the quarry with the stretching of the main direction of movement of the streams of surface and groundwater, which feed and feed the river south of the Buh.

On the examples given, the development of deformation processes is shown in the technogenic interaction (external debris of overburden, quarry, internal debris) and the natural environment. The foregoing makes it possible to conclude that at present, when calculating the stability of objects of an industrial environment, they do not take into account their location in the natural environment, the change in the properties and characteristics of the natural environment under anthropogenic stress.

\section{Conclusions}

Mining industry is the main in violation of the natural environment and the creation of technogenic.

Disrupted massifs include not only open recesses, underground workings, but also territories that have undergone changes in natural properties as a result of mining activities. An example of this category of disturbed environment is the geological environment (massif and terrestrial surface, aquifers and surface runoff) within the radius of the depression funnel. It has been established that during water descents rock compaction and their settling occur, which in turn leads to such negative effects as flooding and dewatering, while the area of disturbed lands depends directly on the area occupied by mining works and is always considerably larger than it in terms of and in depth.

Due to the fact that the natural, disturbed and technogenic environments are in direct contact with each other (both in plan and in depth), there is a series of interconnections between them that affect the general state of the environment.

Each of these environments has its own unique properties, different from natural ones, which depend on a number of technological and geomechanical processes, conditions of formation. In the process of interaction there is a violation of the equilibrium state of the natural environment, which manifests itself in the formation of landslides and gaps, the flooding of territories, the decline of soil fertility.

Future research should be directed to the study of natural geological environment disturbances and technogenic features of the formation, the laws of the formation of their new properties, as well as the scientific rationale and development of technical solutions that focused on the restoration of technogenic and disturbed geological environment properties that correspond to the natural.

\section{References}

1. O. Decka, H. Baroudib, A. Hosnic, Y. Gueniffey. International Journal of Rock Mechanics and Mining Sciences. 105. 62-72 (2018). doi: 10.1016/j.ijrmms.2018.03.010

2. G. Zhang, F. Wang, H. Zhang, H. Tang, H. Li, Y. Zhong. International Journal of Rock Mechanics and Mining Sciences. 106. 319-328 (2018). doi: 
10.1016/j.ijrmms.2018.04.016

3. Y.-M. Wu, H.-X. Lan, X. Gao, L.-P. Li, Z.-H. Yang. Engineering Geology. 195. 63-69 (2015). doi: 10.1016/j.enggeo.2015.05.022

4. B.R. Rakishev, K. Seituly, O.S. Kovrov. Beijing International Symposium on Land Reclamation and Ecological Restoration LRER 2014 (October 16-19, 2014, Beijing, China). 1. 583-588 (2014)

5. O.M.Shashenko, O.S. Kovrov. Scientific Bulletin of National Mining University. 6 (156). 54-59 (2016)

6. A.A. Garakani, S. M.Haeri, A. Khosravi, G. Habibagahi. Engineering Geology. 195. 2841 (2015). doi: 10.1016/j.enggeo.2015.05.026

7. J.P. Malizia, A. Shakoor. Engineering Geology. 244. 125-131 (2018). doi: 10.1016/j.enggeo.2018.07.028

8. K. Kukemilks, J.-F. Wagner, T. Saks, P. Brunner. Landslides. 15. (11). 2267-2278 (2018). doi: 10.1007/s10346-018-1038-5

9. V. Christelis, A.G. Hunges. Environmental Modeling and Software. 107. 298-306. (2018). doi: 10.1016/j.envsoft.2018.05.004

10. Tsytovich, N.A. (1979). Mekhanika gruntov. Moskva: Vysshaya shkola

11. Chetverik, M.S., Bubnova, Ye.A., Androshchuk, Ye.V., Havryuk, G.F. (2003). Opredelenie osedaniy zemnoy poverkhnosti pri vodoponizhenii, obezvozhivanii vodonosnykh gorizontov. Metallurgical and Mining Industry. 6. 74-76

12. M. Chetverik, O. Bubnova, K. Babii, O. Shevchenko, S. Moldabaev. Mining of Mineral Deposits. 12 (4). 63-72 (2018)

13. Chetverik, M.S., Bubnova, Ye.A., Uvarova, L.I. (2005). Vliyanie narusheniya geologicheskoy sredy pri gornykh rabotakh na podtoplenie territoriy. Metallurgical and Mining Industry. 3. 80-83

14. Peregudov, Yu.V., Peregudov, V.V. (2016). Obosnovanie technologii vedeniya otkrytykh gornykh rabot pri vovlechenii $\mathrm{v}$ otrabotku podrabotannykh bortov karera. Geo-Technical Mechanics. 129. 92-97

15. Tsirel, S.V., Haponov, S.V., Pavlovich, A.A. (2013). Granulometricheskiy sostav, sdvigovaya prochnost razrushennykh gornykh porod i ikh vliyanie na ustoichivost otvalov. Gornyy informatsionno-analiticheskiy byulleten, 12, 12

16. Chetverik, M.S., Bubnova, Ye.A. (2010). Formirovanie technogennoy geologicheskoy sredy $\mathrm{i}$ ee vzaimosvyaz $\mathrm{s}$ prirodniy. Vestnik Krivorozhskogo technicheskogo universiteta. $25.83-87$ 